
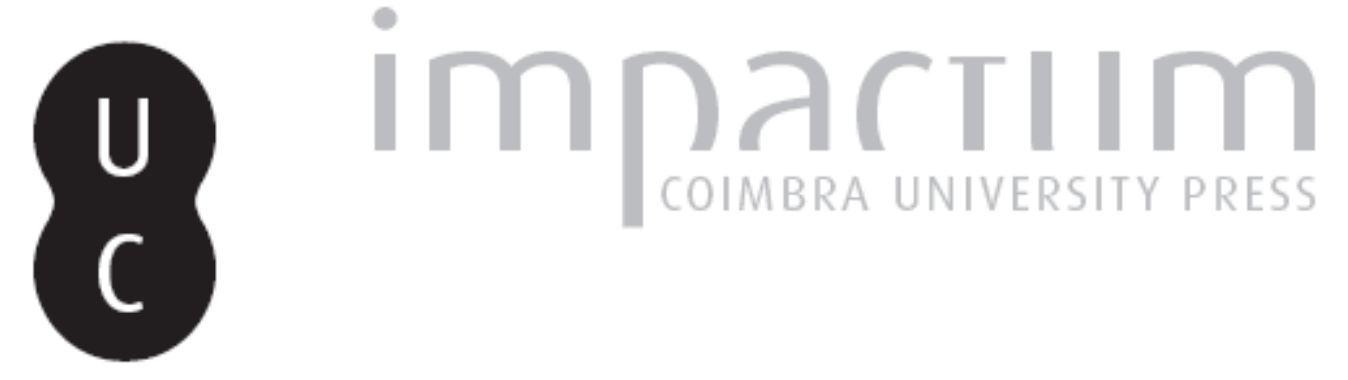

\title{
Anderson, Peter J. (2015): Seneca: selected dialogues and consolations. Indianapolis; Cambridge, Hackett publishing company, Inc.
}
Autor(es):
Dinucci, Aldo

Publicado por: Imprensa da Universidade de Coimbra

URL

persistente:

URI:http://hdl.handle.net/10316.2/42803

DOI:

DOI:https://doi.org/10.14195/1984-249X_21_11

Accessed : $\quad$ 26-Apr-2023 16:28:43

A navegação consulta e descarregamento dos títulos inseridos nas Bibliotecas Digitais UC Digitalis, UC Pombalina e UC Impactum, pressupõem a aceitação plena e sem reservas dos Termos e Condições de Uso destas Bibliotecas Digitais, disponíveis em https://digitalis.uc.pt/pt-pt/termos.

Conforme exposto nos referidos Termos e Condições de Uso, o descarregamento de títulos de acesso restrito requer uma licença válida de autorização devendo o utilizador aceder ao(s) documento(s) a partir de um endereço de IP da instituição detentora da supramencionada licença.

Ao utilizador é apenas permitido o descarregamento para uso pessoal, pelo que o emprego do(s) título(s) descarregado(s) para outro fim, designadamente comercial, carece de autorização do respetivo autor ou editor da obra.

Na medida em que todas as obras da UC Digitalis se encontram protegidas pelo Código do Direito de Autor e Direitos Conexos e demais legislação aplicável, toda a cópia, parcial ou total, deste documento, nos casos em que é legalmente admitida, deverá conter ou fazer-se acompanhar por este aviso.

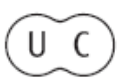




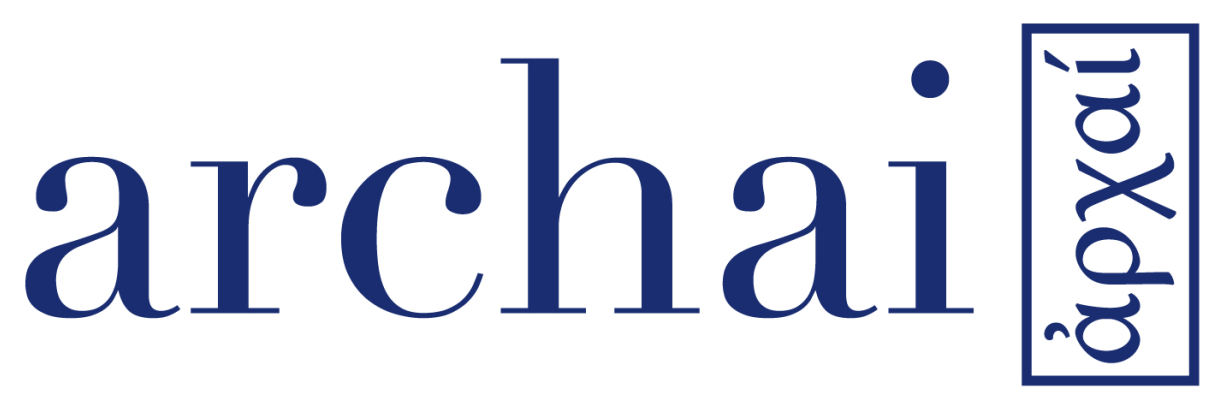

Revista sobre as origens do pensamento ocidental Journal on the Origins of Western Thought

21 | sep.-dec. 2017 


\section{Anderson, Peter J. (2015). SENECA: SELECTED DIALOGUES AND CONSOLATIONS. INDIAN- apolis; Cambridge, Hackett Publishing Company, Inc.}

DINUCCI, A. (2017). Review: Anderson, Peter J. (2015). Seneca: selected dialogues and consolations. Indianapolis; Cambridge, Hackett Publishing Company, Inc. Archai no21, sep.-dec., p. 337-340

DOI: https://doi.org/10.14195/1984-249X_21_11

This volume presents a selection of Seneca's dialogues and consolations. It is composed of introduction, the translations of selected Seneca's dialogues and consolations, biographical information of key individuals, glossary of Latin words, and index of historical persons. The five parts of the book are thus briefly described and evaluated below.

The Introduction is divided into eleven subsections. In the first sub-section, Anderson presents

archai送

no 21 , sep.-dec. 2017 


\section{archai 國}

no 21 , sep.-dec. 2017

Aldo Dinucci: 'Anderson, Peter J. (2015). Seneca: selected dialogues and consolations, Indianapolis; Cambridge, Hackett Publishing Company, Inc., p. $337-340$ a well-written account of Seneca's life (p. xi- xiii). Concerning the philosopher's exile after his implication in an adulterous affair with Julia Livilla, Anderson points out that almost all ancient sources consider Seneca not guilty. A weak point in this argument is that Anderson does not mention the referred primary historical sources, which would be useful to the reader.

The next sub-section deals with the literary qualities of Seneca's philosophical writings. Anderson correctly points out that literary form and philosophy are, in Seneca, two sides of the same coin, noting that, through these writings, Seneca is simultaneously aiming at showing literary excellence and at philosophically persuading the reader.

In the third sub-section ("A note on the translations"), Anderson discusses the difficulties to render Seneca's dialogues in English. In order to achieve this, the translator - based on Lindsay's Oxford classical text - tries to replicate Seneca's prose, consistently rendering the following six key words: animus as "spirit", mens as "mind", virtus as "virtue", otium as "retirement", bonum as "good" and malum as "bad".

The next sub-section examines the interplay between Seneca and Stoicism. In the historical account of the Stoic school, however, Anderson does not mention Diogenes of Babylon. Some information about him should be provided, as he was the first Stoic philosopher in Rome, being sent to the Eternal City (together with the Academic Carneades and the Peripatetic Critolaus) in 155 BC to appeal a fine, and to deliver public lectures on Greek philosophy, 
which much impressed the Romans (cf. Aulus Gellius, Attic Nights, vii. 14; Cicero, Academica, ii. 45).

After the historical account, Anderson makes two important assertions: in the first place, in Seneca's time, Stoicism was a "holistic practice of a set of principles and belief" (p. xviii), which is in marked contrast to the contemporary conception of philosophy; secondly, there are centuries of other philosophers' reflections behind Seneca's arguments.

The next sub-sections present and clarify the following Stoic reflections and concepts that underlie Seneca's philosophical works: the concept of a providential and living god (p. xx), the celebrated expression "to live according nature", the idea that each person is responsible for her or his actions through the rational capacity and the use of impressions (phantasiai), the concept of oikeoisis (p. xxii), and the indifferents (adiaphora - p. xxiii).

In this latter sub-section, Anderson correctly notes that, for the Stoics, things as wealth (which was the same of Seneca's case) and poverty are indifferent and, therefore, cannot guarantee happiness (p. xxiv), which is an important thing to note, as sometimes Seneca's wealthy is regarded as inconsistent with his claims of being a Stoic. In fact, for the Stoics, wealthy can be used for the good or for the bad, as everything else which is indifferent.

The introduction ends with three informative sub-sections: the dating and the addresses of the dialogues and consolations, and a further reading sub-section.

\section{$\operatorname{archai}$ 苃}

no 21, sep.-dec. 2017

Aldo Dinucci: 'Anderson, Peter J. (2015). Seneca: selected dialogues and consolations, Indianapolis; Cambridge, Hackett Publishing Company, Inc,' p. $337-340$ 


\section{archai圈}

no 21, sep.-dec. 2017

Aldo Dinucci: 'Anderson, Peter J. (2015). Seneca: selected dialogues and consolations, Indianapolis; Cambridge, Hackett Publishing Company, Inc.' p. $337-340$
Anderson translates the following Seneca's works: "On providence", "On the resolute nature of the wise man", "Consolation to Marcia", "On the happy life", "On retirement", "On serenity of the spirit", "On the shortness of life", "Consolation to Polybius", "Consolation to his mother Helvia". The subtitles of these works are the original and correspondent ones in Latin. My only suggestion with regard to the translation of the titles is the rendering of $D e$ constantia sapientis as "On the resolute nature of the wise man", which would be better translated as "On the firmness of the wise man".

Anderson's translations of Seneca's selected works are sound. Elucidative footnotes, mainly concerning individuals and historical facts mentioned by Seneca, are supplied. The book ends with biographical information for key individuals, a glossary of Latin words and an index of historical persons.

In summary, the book provides good translations and plenty information concerning Seneca's dialogues and consolations. Thus, it is an excellent tool for students and teachers of Latin literature and Stoic philosophy.

Submitted in November and accepted for publication in December, 2015 